\title{
Whole Blood Assays to Identify Th1 Cell Antigens and Peptides Encoded by Mycobacterium tuberculosis-Specific RD1 Genes
}

\author{
Shumaila N.M. Hanif ${ }^{a}$ Abdulsalam M. El-Shammy ${ }^{b}$ Rajaa Al-Attiyah ${ }^{a}$ \\ Abu S. Mustafa ${ }^{\mathrm{a}}$ \\ ${ }^{a}$ Department of Microbiology, Faculty of Medicine, Kuwait University, and ${ }^{b}$ Chest Disease Hospital, \\ Ministry of Health, Kuwait
}

\section{Key Words}

Tuberculosis • Whole blood assays • Th1 cell antigens •

Region of difference $1 \cdot$ Peptides

\begin{abstract}
Objective: To identify Th1 cell-stimulating antigens/peptides encoded by the genes predicted in the Mycobacterium tuberculosis-specific genomic region of difference (RD)1, deleted in Mycobacterium bovis Bacille Calmette-Guérin (BCG), by using synthetic peptides and whole blood from tuberculosis (TB) patients. Materials and Methods: Heparinized peripheral blood was obtained from culture-proven pulmonary TB patients $(n=16)$ attending the Chest Disease Hospital, Kuwait. Whole blood was diluted with tissue culture medium RPMI-1640 and tested for Th1 cell stimulation using antigen-induced proliferation and interferon- $\gamma$ (IFN- $\gamma$ ) secretion assays. The antigens included a peptide pool of 220 peptides covering the sequence of 12 open reading frames (ORFs) of RD1 (RD1 mix), peptide pools of RD1 ORF5 $\left(\mathrm{ORF} 5_{\text {mix }}\right)$, ORF6 (ORF6 $\left.{ }_{\text {mix }}\right)$ and ORF7 (ORF7 $\left.7_{\text {mix }}\right)$, and individual peptides of ORF6 (P6.1-P6.6) and ORF7 (P7.1-P7.6). M. tuberculosis culture filtrate, cell walls and whole-cell $M$. bovis BCG were used as complex mycobacterial antigens. The results obtained with different antigens and peptides were statistically analyzed for significant differences using $Z$ test. Results: The complex mycobacterial antigens (culture fil-
\end{abstract}

trate, cell walls and $M$. bovis $\mathrm{BCG}$ ) and $\mathrm{RD} 1_{\text {mix }}$ induced comparable $(p>0.05)$ positive antigen-induced proliferation and IFN- $\gamma$ responses with whole blood from TB patients. However, the positive IFN- $\gamma$ responses induced by $\mathrm{ORF} 6_{\text {mix }}$ and $\mathrm{ORF}_{\text {mix }}$ were higher than ORF5 $5_{\text {mix }}$. Among the individual peptides, P6.4 and P7.1 of ORF6 and ORF7, respectively, induced the highest IFN- $\gamma$ responses, suggesting that these peptides represented the immunodominant Th1 cell epitopes of RD1 ORF6 and ORF7 in the patients tested. Conclusion: The whole blood assays with synthetic peptides are useful to identify Th1 cell antigens/peptides encoded by genes located in M. tuberculosis-specific genomic regions.

Copyright $\odot 2008$ S. Karger AG, Basel

\section{Introduction}

Mycobacterium tuberculosis is among the most successful and poorly understood pathogens of human beings. About one third of the world population is infected with $M$. tuberculosis resulting in about 9 million new cases and 2 million deaths each year [1]. The global problem of tuberculosis (TB) is so grave that the World Health Organization has declared TB 'a global emergency', which is the first declaration of its kind [2]. There are several factors that have contributed to the worldwide increase of $\mathrm{TB}$, including the lack of simple and specific immuno-

\section{KARGER \\ Fax +41613061234 \\ E-Mail karger@karger.ch}

www.karger.com
(C) 2008 S. Karger AG, Basel

$1011-7571 / 08 / 0173-0244 \$ 24.50 / 0$

Accessible online at:

www.karger.com/mpp
Shumaila N.M. Hanif

Department of Microbiology, Faculty of Medicine

Kuwait University, PO Box 24923

13110 Safat (Kuwait)

Tel. +965 498 6556, Fax +965 533 2719, E-Mail shumaila_nida@yahoo.co.in 
logical methods of diagnosis and the nonavailability of a vaccine to provide consistent protection in different populations [3].

Among the immunological methods to diagnose TB, the antigens in purified protein derivative (PPD) of $M$. tuberculosis have been widely used in delayed-type hypersensitivity skin test (tuberculin test) [4]. However, PPD is a crude and poorly defined mixture of mycobacterial antigens, some of which are shared between various species of $M$. tuberculosis complex and environmental nontuberculous mycobacterial species $[3,4]$. The other disadvantages of PPD include the need for patients to return for test reading, variability in test application, reading booster effect and false negative results due to intercurrent immunosuppression [4]. At the vaccine front, Mycobacterium bovis Bacille bilié de Calmette-Guérin (M. bovis BCG) has been used as an anti-TB vaccine for several decades with varying (0-80\%) efficacy in different populations [5]. In addition, the use of $M$. bovis BCG as a vaccine jeopardizes the use of PPD in diagnostic applications because of antigenic cross-reactivity. Thus there is a need to identify M. tuberculosis-specific antigens for diagnostic and vaccine applications.

In the recent years, Th1 cell-based in vitro assays like antigen-induced proliferation and interferon- $\gamma$ (IFN- $\gamma$ ) secretion have been developed to identify M. tuberculosisspecific antigens with potentials for diagnostic applications and developing new vaccines [6-11]. However, these in vitro assays mostly require the isolation of peripheral blood mononuclear cells (PBMC) from the whole blood before setting up an experiment [12-15]. Isolation of PBMC is technically demanding, requires additional equipment and reagents and thus increases the cost of the test. In addition, isolation of PBMC requires at least 5-10 $\mathrm{ml}$ of blood, which in certain situations, e.g. pediatric patients, may be difficult to obtain. Hence to overcome these problems associated with PBMC isolation, we investigated the possibility of using whole blood from TB patients to identify the Th1 cell-stimulating antigens and peptides encoded by $M$. tuberculosis-specific region of difference (RD)1 genes, which are deleted in M. bovis BCG.

\section{Materials and Methods}

Mycobacterial Antigens and Peptides

Culture filtrate and cell walls of $M$. tuberculosis were provided by Dr. P.J. Brennan (Colorado State University, Fort Collins, Colo., USA) through the repository of tuberculosis research materials (NIAID, NIH contract No. AI-25147). A total of 220 synthetic peptides (each peptide 25 amino acid in length and overlapping
Table 1. Gene annotation, gene name and length of the proteins encoded by genes predicted in RD1 of $M$. tuberculosis $\mathrm{H} 37 \mathrm{Rv}$

\begin{tabular}{llll}
\hline Gene annotation & Gene name & $\begin{array}{l}\text { Protein length } \\
\text { (number of } \\
\text { amino acids) }\end{array}$ \\
\cline { 1 - 2 } ORF & Rv designation & & amin \\
ORF2 & Rv3871 & rv3871 & 591 \\
ORF3 & Rv3872 & pe35 & 98 \\
ORF4 & unknown & orf4 & 139 \\
ORF5 & Rv3873 & ppe68 & 371 \\
ORF6 & Rv3874 & esxb (cfp10) & 100 \\
ORF7 & Rv3875 & esxa (esat6) & 95 \\
ORF8 & unknown & orf8 & 139 \\
ORF9 & Rv3876 & rv3876 & 666 \\
ORF10 & Rv3877 & rv3877 & 552 \\
ORF11 & Rv3878 & rv3878 & 280 \\
ORF12 & unknown & orf12 & 563 \\
ORF13 & Rv3879 & rv3879c & 46 \\
ORF14 & unknown & orf14 & 262 \\
ORF15 & unknown & orf15 & 262 \\
\hline
\end{tabular}

with the neighboring peptides by 10 residues) covering entire coding sequences of 12 RD1 open reading frames (ORFs; ORFs 2-11, ORF14 and ORF15) [16] were purchased as lyophilized powders from Genemed Synthesis Inc., San Francisco, Calif., USA. Further details about these ORFs regarding gene annotation in $M$. tuberculosis $\mathrm{H} 37 \mathrm{Rv}$ ( $\mathrm{Rv}$ designations), gene name and length of encoded proteins are given in table 1. Each peptide was suspended in phosphate-buffered saline ( $\mathrm{pH}$ 7.2) at a concentration of $1 \mathrm{mg} / \mathrm{ml}$, and frozen at $-20^{\circ} \mathrm{C}$. From this stock, a master pool of all the peptides $\left(\mathrm{RD} 1_{\text {mix }}\right)$ and pools corresponding to ORF5 $\left(\mathrm{ORF} 5_{\text {mix }}\right)$, ORF6 (ORF6 $\left.6_{\text {mix }}\right)$, ORF7 (ORF7 mix $\left._{\text {mix }}\right)$ were prepared in tissue culture medium RPMI-1640 (GIBCO, Invitrogen Co., UK). The optimal concentrations of antigens and peptides for Th1 cell reactivity were determined in dose-response studies by using concentrations of $20,4,0.8$ and $0.016 \mu \mathrm{g} / \mathrm{ml}$.

\section{Antigen-Induced Proliferation and IFN- $\gamma$ Secretion Assays} Using Whole Blood

Heparinized peripheral blood was obtained from PPD-positive pulmonary TB patients $(n=16,15$ males and 1 female, age between 18 and 50 years) attending the Chest Disease Hospital, Kuwait. All of the patients had clinical symptoms and chest radiographs suggestive of TB and were PPD-positive. The diagnosis of pulmonary TB was confirmed by positive culture using sputum specimens. Informed consent was obtained from all the patients and the study was approved by the Ethics Committee, Health Sciences Centre, Kuwait University, Kuwait. The blood from each patient was collected within 1 month of directly observed therapy short course. The blood was diluted with RPMI-1640 (1:10), as reported by Weir et al. [17], and assayed for antigen-induced proliferation and IFN- $\gamma$ secretion, as described previously for PBMC $[18,19]$. In brief, the diluted whole blood samples $(200 \mu \mathrm{l})$ along with different antigens or peptides $(50 \mu \mathrm{l})$ were plated in triplicates into the wells of 96-well tissue culture plates (Nunc). A set 


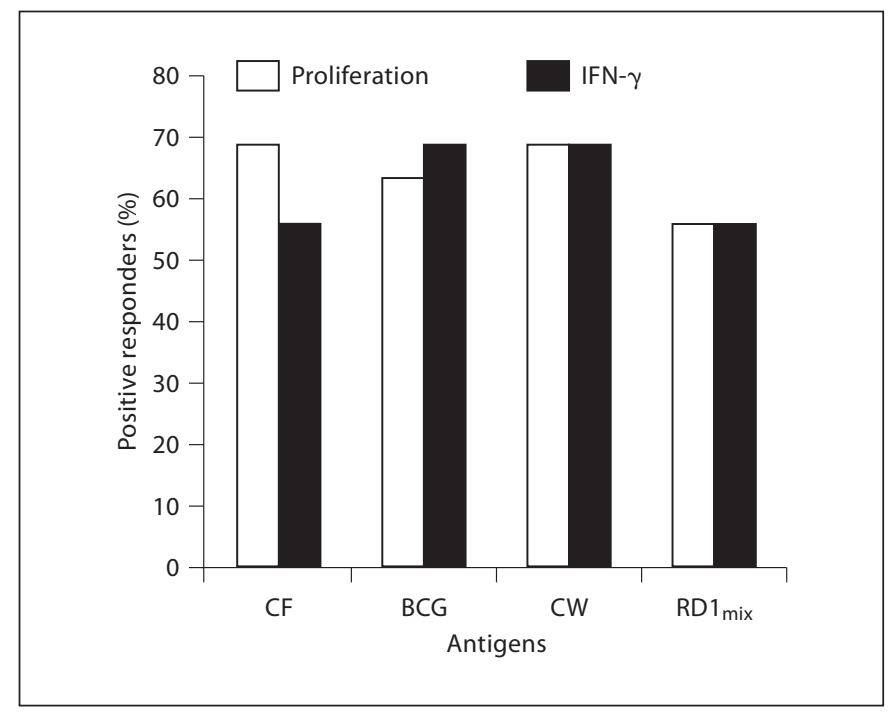

Fig. 1. Percentage of positive responders in antigen-induced proliferation and IFN- $\gamma$ secretion assays. $\mathrm{CF}=$ Culture filtrate; $\mathrm{CW}=$ cell walls.

of three wells did not receive any mycobacterial antigen/peptide and served as a control. The plates were incubated at $37^{\circ} \mathrm{C}$ in an atmosphere of $5 \% \mathrm{CO}_{2}$ and $95 \%$ air. The cultures were pulsed on day 6 with $1 \mu \mathrm{Ci}^{3} \mathrm{H}$-thymidine (Amersham Life Science, Amersham, UK) and the radioactivity incorporated was determined using standard procedures [12]. Average counts per minute (cpm) values from triplicate wells were calculated in response to each antigen/peptide as well as control wells without antigen/peptide.

To quantify IFN- $\gamma$ secreted by cells in the whole blood, supernatants $(75 \mu \mathrm{l})$ from each well of 96 -well plates were collected from the cultures of whole blood before ${ }^{3} \mathrm{H}$-thymidine pulse. The supernatants were kept frozen at $-20^{\circ} \mathrm{C}$ until assayed for IFN- $\gamma$ activity. IFN- $\gamma$ activity in the supernatants was quantitated by using enzyme-linked immunosorbent assay kits purchased from Immunotech, USA according to the manufacturer's instructions.

\section{Interpretation of Antigen-Induced Proliferation and IFN- $\gamma$}

Results

The antigen-induced proliferation responses were considered positive when average cpm values in antigen- or peptide-stimulated cultures exceeded the average cpm values in cultures lacking the antigens or peptides by $50 \%$. Secretion of IFN- $\gamma$ in response to a given antigen or peptide was considered positive when $\Delta$ IFN$\gamma(\Delta$ IFN- $\gamma=$ average IFN- $\gamma$ concentration in antigen- or peptidestimulated cultures minus average IFN- $\gamma$ concentration in cultures lacking antigen or peptide) was $\geq 1.5 \mathrm{IU} / \mathrm{ml}$ [20]. The overall results of antigen-induced proliferation and IFN- $\gamma$ secretion assays with respect to a given antigen or peptide were presented in terms of percent positive responders, which is defined as:

$\%$ positive responders $=$

Number of patients showing a positive response

$$
\text { Number of patients tested }
$$

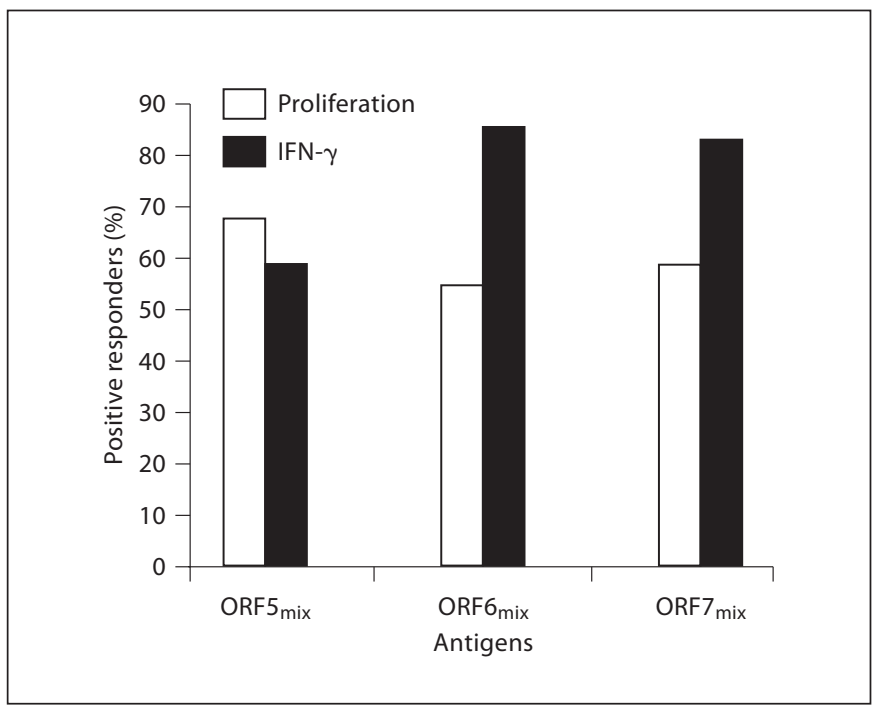

Fig. 2. Percentage of positive responders in antigen-induced proliferation and IFN- $\gamma$ secretion assays in response to peptide pools of ORF5 (ORF5 mix $)$, ORF6 (ORF6 mix $)$ and ORF7 (ORF7 $7_{\text {mix }}$ ).

\section{Statistical Analysis}

The statistical analysis was performed using $\mathrm{Z}$ test to identify significant differences $(p<0.05)$ with respect to percent positive responders in response to various antigens and peptides in antigen-induced proliferation and IFN- $\gamma$ secretion assays.

\section{Results}

The results of antigen-induced proliferation and IFN$\gamma$ assays showed that the best responses were obtained with various antigens/peptides at 20 and $4 \mu \mathrm{g} / \mathrm{ml}$ (data not shown). To save on the cost of the test, further experiments with all the antigens/peptides were performed at $4 \mu \mathrm{g} / \mathrm{ml}$. Statistically similar results $(\mathrm{p}>0.05)$ were obtained in antigen-induced proliferation and IFN- $\gamma$ responses (the blood cells from $56-69 \%$ TB patients proliferated and $56-69 \%$ patients produced IFN- $\gamma$ ) in response to the various complex antigens and $\mathrm{RD} 1_{\text {mix }}$ (fig. 1). These results showed that the antigens represented in $\mathrm{RD} 1_{\text {mix }}$ behaved like complex antigens in the tested Th1 cell assays.

When tested with peptide pools of three RD1 antigens, blood cells secreted lower amounts of IFN- $\gamma$ in response to ORF $5_{\text {mix }}$, as compared to ORF $6_{\text {mix }}$ and ORF7 $7_{\text {mix }}$ (fig. 2). The experiments performed with individual peptides of ORF6 and ORF7 indicated that Th1 cell epitopes were scattered throughout the protein sequences, as all the peptides were stimulatory for $>35 \%$ patients in antigen- 


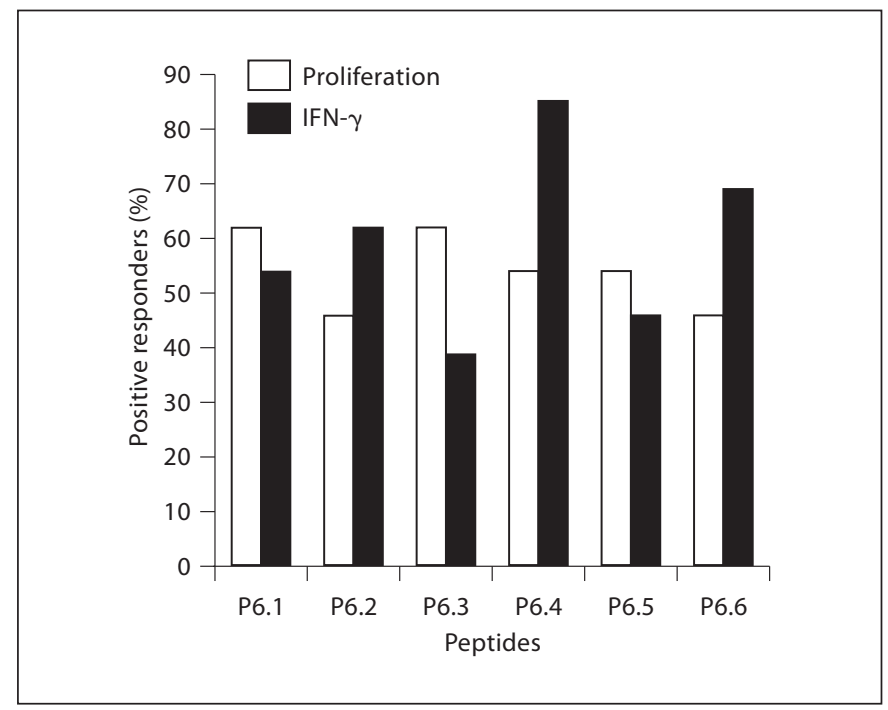

Fig. 3. Percentage of positive responders in antigen-induced proliferation and IFN- $\gamma$ secretion assays in response to individual peptides of ORF6.

induced proliferation and IFN- $\gamma$ assays. However, the best responses were obtained in IFN- $\gamma$ assays with the peptides P6.4 (positive responders $=85 \%$ ) of ORF6 (fig. 3 ) and P7.1 (positive responders $=83 \%$ ) of ORF7 (fig. 4). The IFN- $\gamma$ responses to the peptide P6.4 were significantly higher $(\mathrm{p}<0.05)$ than P6.1, P6.4 and P6.5 of ORF6 and the responses to P7.1 were significantly higher $(\mathrm{p}<0.05)$ than P7.4, P7.5 and P7.6 of ORF7. Taken together, all of the patients tested responded to P6.4 and/or P7.1 in IFN$\gamma$ assays (data not shown). Thus, the peptides P6.4 of ORF6 and P7.1 of ORF7 could be considered immunodominant for inducing IFN- $\gamma$ secretion by peripheral blood of patients with pulmonary TB.

\section{Discussion}

A number of studies towards specific diagnosis of TB have been performed in the past with RD1 antigens and whole blood in IFN- $\gamma$ assays, but these studies have been restricted to only two proteins of RD1 and their peptides, i.e. CFP10 (ORF6) and ESAT6 (ORF7) [20-24]. However, in this study, we have, in addition, used a cocktail of 220 overlapping peptides covering the sequence of $12 \mathrm{RD} 1$ proteins $\left(\mathrm{RD} 1_{\text {mix }}\right)$ and 24 peptides of ORF5 $\left(\mathrm{ORF} 5_{\text {mix }}\right)$ in two different Th1 cell assays, i.e. antigen-induced proliferation and IFN- $\gamma$ secretion. The previous studies with RD1 peptides and whole blood have only used the mix-

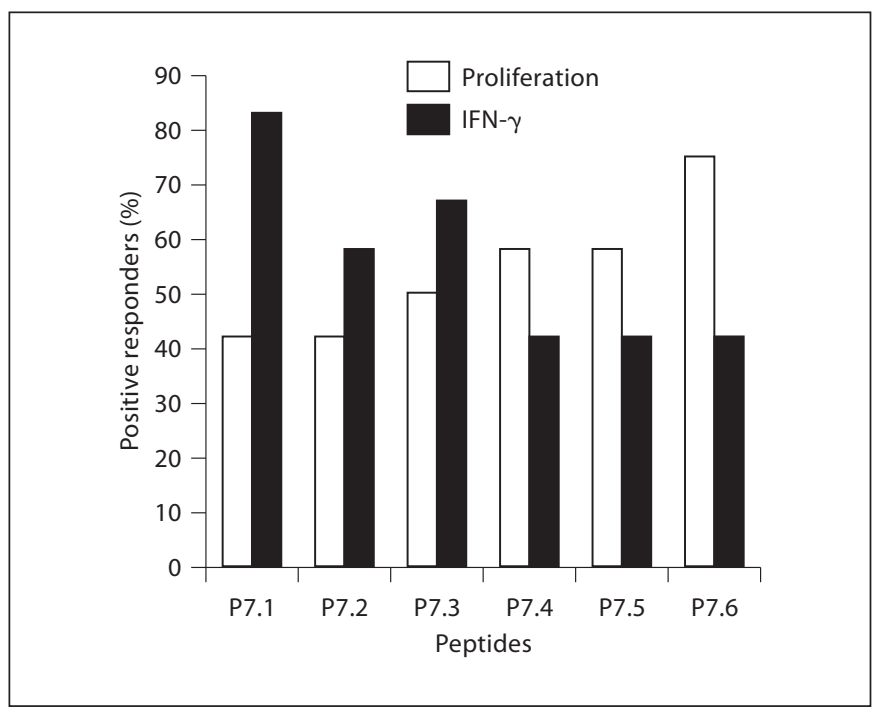

Fig. 4. Percentage of positive responders in antigen-induced proliferation and IFN- $\gamma$ secretion assays in response to individual peptides of ORF7.

tures of overlapping peptides of ORF6 and ORF7, including the commercially available QuantiFERON-TB Gold kit, for IFN- $\gamma$ secretion only [22-24]. In this study, we have tested pools of six overlapping peptides corresponding to ORF6 and ORF7 (ORF6 $6_{\text {mix }}$ and ORF7 mix $_{\text {mix }}$, respectively) as well as the individual peptides of these proteins with whole blood for antigen-induced proliferation and IFN- $\gamma$ secretion. Our results with peptide pools show that $\mathrm{RD} 1_{\text {mix }}$ and $\mathrm{ORF} 5_{\text {mix }}$ have sensitivities similar to complex mycobacterial antigens, i.e. between 60 and $70 \%$ in both assays, but improved sensitivities (85\%) were observed with $\mathrm{ORF} 6_{\text {mix }}$ and ORF7 $7_{\text {mix }}$, which are similar to the sensitivities (89 and 83\%) observed with QuantiFERON-TB Gold kit, that also uses peptide pools of ORF6 and ORF7 [23 and 24, respectively].

The experiments with individual peptides of ORF6 and ORF7 show that Th1 cell epitopes were scattered throughout the sequence of these proteins but peptides P6.4 (AAGTAAQA AVVRFQEAANKQKQELD) and P7.1 (MTEQQWNNFAGIEAAASAIQGNVTSI) were the dominant peptides giving positive responses in 85 and $83 \%$ subjects, respectively. Taken together, these peptides yielded $100 \%$ positive results in the patients tested. In previous studies with selected peptides of ORF6 and ORF7, Goletti et al. [23] observed 81 and 70\% sensitivities with a peptide pool of two peptides of ESAT6 and three peptides of CFP10. Furthermore, the comparisons by Goletti et al. in two independent studies show that their pep- 
tides selected from ORF6 and ORF7 proteins were less sensitive than the overlapping peptides of ORF6 and ORF7 included in the QuantiFERON-TB Gold kit (89 and $83 \%$ sensitivities) [23 and 24 , respectively]. In contrast, in our study, the results of two dominant peptides of ORF6 and ORF7 (P6.4 and P7.1, respectively) taken together show a collective sensitivity of $100 \%$. These differences in sensitivities could be due to several factors including differences in the population of patients tested, differences in the amino acid sequence of the peptides and differences in the assay time point. In previous studies, it has been shown that the optimal time point for detection of IFN- $\gamma$ secreted by whole blood is day $6[17,22]$. This was the time point that we have used in our study, as compared to the 40-hour (day 2) assay reported by Goletti et al. [23, 24], which is suboptimal [17, 22].

The whole blood assays, as compared to the standard assays using PBMC, are relatively simple, require less manipulation and can be used with small quantities of blood, and thus could be used in endemic field situation [21-24]. If used at 1/10 dilution, like in our study, the whole blood assays could be performed with a very small quantity of blood. One milliliter of blood at 1/10 dilution will be enough to seed the cells into 50 wells of 96 -well plates at a final volume of $200 \mu \mathrm{l} /$ well. This will be sufficient to test about 16 different antigens and controls or several concentrations of few antigens, when each antigen/con- centration is tested in triplicate. This amount of blood can easily be obtained with less compliance problems from adults as well as children or when repeated testing is required. Moreover, the diagnostic reagents may contain a single antigen/peptide or a mixture of $M$. tuberculosis-specific antigens and immunodominant peptides; if so, whole blood obtained by a finger prick (i.e. $100 \mu \mathrm{l}$ ) will be enough to perform the test. Thus, whole blood assays with $M$. tuberculosis-specific antigens and peptides could be preferred over PBMC assay in diagnostic and epidemiological investigations.

\section{Conclusion}

Whole blood assays with synthetic peptides are useful to identify Thl cell antigens/peptides encoded by genes located in M. tuberculosis-specific genomic regions. The assay format is suitable to carry out further work on a large scale with the identified antigens/peptides for diagnostic and epidemiological investigations.

\section{Acknowledgments}

The study was funded by the College of Graduate Studies and Kuwait University Research Administration grant MI02/02.

\section{References}

1 Harries AD, Dye C: Tuberculosis. Ann Trop Med Parasitol 2006;100:415-431.

$\checkmark 2$ API Consensus Expert Committee: API TB Consensus Guidelines 2006: Management of pulmonary tuberculosis, extra-pulmonary tuberculosis and tuberculosis in special situations. J Assoc Physicians India 2006;54: 219-234.

-3 Mustafa AS: Biotechnology in the development of new vaccines and diagnostic reagents against tuberculosis. Curr Pharm Biotechnol 2001;2:157-173.

4 Hill PC, Brookes RH, Fox A, Jackson-Sillah D, Lugos MD, Jeffries DJ, Donkor SA, Adegbola RA, McAdam KP: Surprisingly high specificity of the PPD skin test for M. tuberculosis infection from recent exposure in The Gambia. PLoS ONE 2006; 1:e68.

5 Fine PE: Variation in protection by BCG: implications of and for heterologous immunity. Lancet 1995;346:1339-1345.
6 Mustafa AS, Amoudy HA, Wiker HG, Abal AT, Ravn P, Oftung F, Andersen P: Comparison of antigen-specific T-cell responses of tuberculosis patients using complex or single antigens of Mycobacterium tuberculosis. Scand J Immunol 1998;48:535-543.

7 Mustafa AS: Development of new vaccines and diagnostic reagents against tuberculosis. Mol Immunol 2002;39:113-119.

$\checkmark 8$ Al-Attiyah R, Madi N, El-Shamy AS, Harald W, Andersen P, Mustafa AS: Cytokine profiles in tuberculosis patients and healthy subjects in response to complex and single antigens of Mycobacterium tuberculosis. FEMS Immunol Med Microbiol 2006;47: 254-261.

-9 Mustafa AS: Mycobacterial gene cloning and expression, comparative genomics, bioinformatics and proteomics in relation to the development of new vaccines and diagnostic reagents. Med Princ Pract 2005;14:27-34.

10 Pai M, Riley LW, Colford JM Jr: Interferongamma assays in the immunodiagnosis of tuberculosis: a systematic review. Lancet Infect Dis 2004;4:761-776.
11 De Groot AS, McMurry J, Marcon L, Franco J, Rivera D, Kutzler M, Weiner D, Martin B: Developing an epitope-driven tuberculosis (TB) vaccine. Vaccine 2005;23:2121-2131.

- 12 Al-Attiyah R, Shaban FA, Wiker HG, Oftung F, Mustafa AS: Synthetic peptides identify promiscuous human Th1 cell epitopes of the secreted mycobacterial antigen MPB70. Infect Immun 2003;71:1953-1960.

13 Al-Attiyah R, Mustafa AS, Abal AT, Madi NM, Andersen P: Restoration of mycobacterial antigen-induced proliferation and interferon-gamma responses in peripheral blood mononuclear cells of tuberculosis patients upon effective chemotherapy. FEMS Immunol Med Microbiol 2003;38:249-256.

14 Al-Attiyah R, Mustafa AS: Computer-assisted prediction of HLA-DR binding and experimental analysis for human promiscuous Th1-cell peptides in the $24 \mathrm{kDa}$ secreted lipoprotein (LppX) of Mycobacterium tuberculosis. Scand J Immunol 2004;59:16-24. 
15 Mustafa AS, Shaban FA: ProPred analysis and experimental evaluation of promiscuous T-cell epitopes of three major secreted antigens of Mycobacterium tuberculosis. Tuberculosis (Edinb) 2006;86:115-124.

16 Amoudy HA, Al-Turab MB, Mustafa AS: Identification of transcriptionally active open reading frames within the RD1 genomic segment of Mycobacterium tuberculosis. Med Princ Pract 2006;15:137-144.

17 Weir RE, Morgan AR, Britton WJ, Butlin CR, Dockrell HM: Development of whole blood assay to measure $\mathrm{T}$ cell responses to leprosy: a new tool for immuno-epidemiological field studies of leprosy immunity. J Immunol Methods 1994;176:93-101.

18 Al-Attiyah R, Mustafa AS, Abal AT, El-Shamy AS, Dalemans W, Skeiky YA: In vitro cellular immune responses to complex and newly defined recombinant antigens of $M y$ cobacterium tuberculosis. Clin Exp Immunol 2004;138:139-144.
19 Mustafa AS, Abal AT, Shaban F, El-Shamy AM, Amoudy HA: HLA-DR binding prediction and experimental evaluation of T-cell epitopes of mycolyl transferase 85B (Ag85B), a major secreted antigen of Mycobacterium tuberculosis. Med Princ Pract 2005;14:140146.

20 Ravn P, Munk ME, Andersen AB, Lundgren B, Lundgren JD, Nielsen LN, Kok-Jensen A, Andersen P, Weldingh K: Prospective evaluation of a whole-blood test using Mycobacterium tuberculosis-specific antigens ESAT- 6 and CFP-10 for diagnosis of active tuberculosis. Clin Diagn Lab Immunol 2005;12:491496.

21 Brock I, Munk ME, Kok JA, Andersen P: Performance of whole blood IFN-gamma test for tuberculosis diagnosis based on PPD or the specific antigens ESAT- 6 and CFP-10. Int J Tuberc Lung Dis 2001;5:462-467.
22 Scholvinck E, Wilkinson KA, Whelan AO, Martineau AR, Levin M, Wilkinson RJ: Gamma interferon-based immunodiagnosis of tuberculosis: comparison between wholeblood and enzyme-linked immunospot methods. J Clin Microbiol 2004;42:829831.

23 Goletti D, Vincenti D, Carrara S, Butera O, Bizzoni F, Bernardini G, Amicosante M, Girardi E: Selected RD1 peptides for active tuberculosis diagnosis: comparison of a gamma interferon whole-blood enzyme-linked immunosorbent assay and an enzyme-linked immunospot assay. Clin Diagn Lab Immunol 2005;12:1311-1316.

24 Goletti D, Carrara S, Vincenti D, Saltini C, Rizzi EB, Schinina V, Ippolito G, Amicosante M, Girardi E: Accuracy of an immune diagnostic assay based on RD1 selected epitopes for active tuberculosis in a clinical setting: a pilot study. Clin Microbiol Infect 2006; 12:544-550. 